\title{
The Practice of Female Genital Mutilation/Cutting (FGM/C) in the Work Area of the Tangerang City Health Center
}

\author{
Artika Savera Maulidha Anwar ${ }^{1}$, Dwi Izzati Budiono ${ }^{2}$, Pudji Lestari ${ }^{3}$ \\ Departement of Midwifery Education, Faculty of Medicine University Airlangga 60132, Surabaya, East Java, Indonesia
}

Corresponding Author : artika.savera.maulidha-2020@fk.unair.ac.id

\begin{abstract}
One of the problems of women's reproductive health that still exists today is the dangerous practice carried out on the genitals of girls, namely FGM/C (Female Genital Mutilation/Cutting) or commonly known as female circumcision. According to the data obtained, the practice of FGM/C is mostly carried out by midwives, while in the competency standard of midwives this practice is not taught in the midwifery education curriculum. This study aims to determine the techniques used by midwives in practicing FGM/C and the midwife's view of the government's role regarding this practice in the Tangerang City Health Center Work Area. This study used a qualitative research design with a phenomenological approach. The technique used is purposive sampling with a total of 7 respondents. The most commonly used FGM/C technique was to clean the genitals of baby girls with gauze and betadine or water. From the midwife's opinion, the government's role is still lacking in following up on the ban on FGM/C practices. The conclusion is The FGM/C technique used by midwives is to clean and use a needle in the genital area of a baby girl without any injury, however the role of the government must still be carried out because it is feared that there are people who practice this FGM/C practice which is more extreme and dangerous for baby girls.
\end{abstract}

Keywords: FGM/C, female circumcision, FGM/C techniques, the role of the government

\section{Introduction}

Until now, there are still many women's reproductive health problems in Indonesia that are related to gender discrimination against women which results in the non-fulfillment of women's reproductive rights (1). The problem of women's reproductive health that still exists today is a dangerous practice carried out on the genitals of girls, namely Female Genital Mutilation/Cutting (FGM/C) $(2,3)$.

The health impacts of this FGM/C practice are generally related to infections, bladder problems and infertility, keloids, problems with menstruation, and obstetric complications that occur during pregnancy, childbirth and even the postpartum period (4). According to UNICEF in the Statistical Profile on Female Genital Mutilation, Indonesia is the third country with the highest prevalence (49\%) that has undergone FGM/C (5).

Nationally, the percentage of ever circumcised in girls aged $0-11$ years was $51.2 \%$ then in the description of FGM/C by province in Indonesia, Banten province is one of the provinces with the highest 
percentage of FGM/C (79.2\%) and the most (55.5\%). 8\%) was carried out in an urban context rather than in rural or remote areas, such as in the city of Tangerang $(78.1 \%)$ where FGM/C practices were still prevalent, and the highest FGM/C practice in Indonesia was carried out by midwives $(50.9 \%)(6,7)$.

The practice of FGM/C in Indonesia so far is mostly carried out by midwives when the baby is born (2), even though this practice is not contained in the competency standards of midwives. In addition, the implementation of P2GP has never been taught in the health worker education curriculum. Thus, it can be said that this practice is a violation of the code of ethics for cutting or injuring healthy female genital tissue (8).

Based on the above background, this study aims to determine the techniques used by midwives in practicing FGM/C and the midwife's view on the role of the government regarding FGM/C practices in the work area of the Tangerang City Health Center..

\section{Methods}

This study uses a qualitative method with a phenomenological approach. This study took as many as 7 participants with purposive sampling technique and was carried out in the working area of the Tangerang City Health Center. The inclusion criteria in this study were midwives who had a place of practice in the work area of the Tangerang City Health Center. Data collection techniques obtained from the results of in-depth interviews (Indepth Interview). This research protocol has followed the ethical feasibility of the Health Research Ethics Committee, Faculty of Medicine, Airlangga University with the number 199/EC/KEPK/FKUA.2021.

\section{Results}

The number of participants in this study who agreed to conduct in-depth interviews were 7 people. In the research analysis, each participant was given a participant code. Based on the data on education and length of work in the PMB participants' area in table 1, it is known that the majority of them have worked for over 12 years.

Table 1. participant characteristics

\begin{tabular}{lllll}
\hline $\begin{array}{l}\text { Participant } \\
\text { code }\end{array}$ & $\begin{array}{l}\text { Age } \\
\text { (year) }\end{array}$ & Religion & $\begin{array}{l}\text { Last } \\
\text { education }\end{array}$ & $\begin{array}{l}\text { length of } \\
\text { work in the } \\
\text { practice area }\end{array}$ \\
\hline P1 & 34 & Islam & Diploma 3 & 8 \\
P2 & 33 & Christian & Diploma 3 & 3 \\
P3 & 40 & Islam & Diploma 3 & 12 \\
P4 & 47 & Islam & Diploma 3 & 15 \\
P5 & 34 & Islam & Diploma 3 & 3 \\
P6 & 45 & Islam & Diploma 4 & 20 \\
P7 & 36 & Islam & Diploma 4 & 15 \\
\hline
\end{tabular}

From the results of in-depth interviews, there are 2 techniques that are usually used by midwives in practicing FGM/C, namely cleaning the genitals of baby girls and using needles. 


\section{Cleaning the female genitals}

Based on the results of in-depth interviews, several midwives argued that the FGM/C technique that is usually used is to clean the genitals of baby girls.

"Just cleaned with gauze... betadine gauze... so it's as if the patient believes that his child has been circumcised." (P5, 34 years old)

"[...]We clean the labia and clitoris with gauze... gauze that has been moistened with warm water $[\ldots]$ "“(P2, 33 years old $)$

Cleaning the genitals of baby girls is usually done using gauze and betadine or water. They clean the genitals of white dirt that sticks around the genitals of baby girls.

\section{Using a needle}

The interview results show that another technique used in FGM/C practice is to use a needle.

"Yes... well, just clean the clitoris like a condition. So actually no one was injured, so God willing, the baby won't lose either because the clitoris isn't hurt, it's just like cleaning, like in a little point." (P3, 40 years old)

"So it's a needle, needle $23 \ldots$ what's there...then I open it and I hold the gauze with betadine right [...]" (P7, 36 years old)

In this technique the midwife only attaches the needle to the clitoris and accompanied by covering the genitals of the baby girl using gauze.

\section{The role of the government}

From the interviews obtained, the majority of midwives are of the opinion that the government has not played a significant role in the prohibition of the practice of FGM/C.

"So the role of the government for counseling, I think it's still lacking, because it's only in the KIA book... right, not everyone reads the KIA book in detail, there are also flipcharts and guidelines as far as I know for health workers not to practice P2GP for counseling also to the community, but it's rarely done by health workers..." (P2, 33 years old)

"So far there has been no action - what kind of action, maybe it's just circulars like that, it's just me... because I'm... what's the name... BPM continues to hold IBI meetings that are rare, so maybe... the government conveys it to the heads of branches or branch heads, that's all." (P4, 47 years old)

They admitted that there was no action from the government regarding the prohibition of the practice of $\mathrm{FGM} / \mathrm{C}$, and also that they had never conducted socialization regarding the prohibition of this practice.

\section{Discussion}

According to WHO, FGM/C is classified into 4 types, type 1 is partial or complete cutting of the clitoris, type 2 is partial or complete cutting of the clitoris and labia minora, type 3 is narrowing of the vaginal opening, and type 4 is a dangerous procedure on the female genitalia for the purpose of nonmedical (9). Research conducted in The Gambia, United Arab Emirates and Ethiopia, the most common types being type 1 and type $2(10-12)$. Then, another study conducted in the Netherlands showed that the most common type was type 3 (13). Meanwhile, from the results of this study, the technique used by the midwife was to use a needle that was only attached to the clitoris and only to clean the genitals of baby girls using gauze and betadine or water. 
In the types of P2GP it can cause direct complications, such as bleeding, infection, sepsis and even death (14). Meanwhile, long-term complications that can occur are pain during sexual intercourse, reduced sexual satisfaction, and complications during childbirth $(15,16)$. In this study, midwives did not do as in the types of FGM/C described by WHO, because they did not injure or cut the genitals of baby girls. So, it can be said that the practice carried out by the midwife does not cause complications.

In this study, the position of the midwife was in a dilemma between following the demands of society and socializing the dangers of this FGM/C practice, so that the midwife only cleaned the genitals of female babies. In dealing with social pressures, health workers only clean the female genitalia without injuring or cutting it and without the knowledge of the parents (2).

The regulations or laws governing the practice of FGM/C are still not strong enough. In Indonesia, the state does not yet have a firm attitude towards the practice of FGM/C (17). Latin American countries also do not have specific laws or legal provisions against this practice of FGM/C (18). Even though the practice of FGM/C is illegal (19).

The government's role is important regarding the prohibition of FGM/C practices, Komnas Perempuan in their press release provides several recommendations for the government regarding FGM/C practices, one of which is to disseminate information to both the community and health workers (17). Meanwhile, in this study, according to participants' views, the role of the government is still lacking and has not yet had an effect on this phenomenon. Whereas a good strategy to do is to disseminate information to all levels of society that this practice is not only dangerous for women but also includes gender inequality (20).

The Sustainable Development Goals (SDGs) make one of the programs at point 5.3 which is to eliminate harmful practices such as female circumcision/FGM (21). However, in April 2020 UNFPA analyzed the impact of COVID-19 on one of the FGM/C practices, they projected that there might be additional cases of this practice due to a pandemic in the $\mathrm{FGM} / \mathrm{C}$ practice prevention program (22).

\section{Conclusion}

The FGM/C technique used by midwives is to only clean the genitals of the baby girl and use a needle without injuring her, this technique is not included in the types classified by WHO. So, this technique does not give complications to baby girls. The role of the government is important to socialize the prohibition of FGM/C even though what the midwife does not injure the genitals of female babies, it is feared that there are people who practice FGM/C with extreme techniques and can harm baby girls. This study has a limited number of participants and research locations, so it needs to be expanded.

\section{Acknowledgements}

Thanks to all parties who have assisted in the implementation of this research. 


\section{References}

1. Inayati IN, Widanti A, Lucyati A. Ketentuan Tentang Sunat Perempuan Dikaitkan Dengan Asas Gender Dan Nondiskriminatif. Soepra. 2017;2(1):61.

2. Susilastuti DH, Kiswanto E, Widyaningrum N, Purwatiningsih S. Pemotongan / Perlukaan Genitalia Perempuan dan Modernitas. 2017;151.

3. Komnas Perempuan. Hasil Kajian Kualitatif Pemotongan / Pelukaan Genitalia Perempuan ( P2GP ). Hodijah SN, Indraswari, editors. Komisi Nasional Anti Kekerasan Terhadap Perempuan; 2018. p. 1-252.

4. Shakirat GO, Alshibshoubi MA, Delia E, Hamayon A, Ian H. An Overview of Female Genital Mutilation in Africa : Are the Women Beneficiaries or Victims? 2020;12(9).

5. UNICEF. Statistical profile on female genital mutilation/cutting [Internet]. 2020. p. 1-4. Available from: https://data.unicef.org/wp-content/uploads/country_profiles/Indonesia/FGM_IDN.pdf

6. RISKESDAS. RISET KESEHATAN DASAR. 2013. p. 1-306.

7. Riskesdas Provinsi Banten. Pokok-Pokok Hasil Riset Kesehatan Dasar Provinsi Banten 2013 [Internet]. Vol. 2013, Badan Penelitian dan Pengembangan Kesehatan Kemeterian Kesehatan RI. 2013. p. 1-304. Available from: https://www.researchgate.net/publication/280735574?channel=doi\&linkId=55c46f8608aebc967df1cd1c\&showFulltext=true

8. Kementerian Kesehatan R.I. Pedoman Bagi Tenaga Kesehatan Dalam Pencegahan Praktik Pemotongan dan Pelukaan Genitalia Perempuan (P2GP) [Internet]. 2018. p. 1-19. Available from: https://www.ibi.or.id/id/article_view/A20201010002/pedoman-bagi-tenaga-kesehatan-dan-lembar-balik-pencegahan-praktikp2gp-fgm.html

9. WHO. Female genital mutilation [Internet]. 2020 [cited 2021 Mar 26]. Available from: https://www.who.int/news-room/factsheets/detail/female-genital-mutilation

10. Kaplan A, Forbes M, Bonhoure I, Utzet M, Martín M, Manneh M, et al. Female genital mutilation/cutting in The Gambia: Long-term health consequences and complications during delivery and for the newborn. Int J Womens Health. 2013;5(1):323-31.

11. Awar S Al, Al-jefout M, Osman N, Balayah Z, Kindi N Al, Ucenic T. Prevalence, knowledge , attitude and practices of female genital mutilation and cutting ( FGM / C ) among United Arab Emirates population. 2020;1-12.

12. Bogale D, Markos D, Kaso M. Prevalence of female genital mutilation and its effect on women's health in Bale zone, Ethiopia: A cross-sectional study. BMC Public Health. 2014;14(1):1-11.

13. Kawous R, Allwood E, Norbart E, Van Den METC, Muijsenbergh. Female genital mutilation and women's healthcare experiences with general practitioners in the Netherlands: A qualitative study. PLoS One [Internet]. 2020;15(7 July):1-13. Available from: http://dx.doi.org/10.1371/journal.pone.0235867

14. UNFPA. State of the World Population 2020: Against my Will Defying The Practices That Harm Women and Girls and Undermine Equality [Internet]. The United Nations Population Fund. 2020. 1-164 p. Available from: 
https://www.unfpa.org/sites/default/files/pub-pdf/UNFPA_PUB_2020_EN_State_of_World_Population.pdf

15. Nzinga AM, De Andrade Castanheira S, Hermann J, Feipel V, Kipula AJ, Bertuit J. Consequences of Female Genital Mutilation on Women's Sexual Health - Systematic Review and Meta-Analysis. J Sex Med. 2021;18(4):750-60.

16. Madzou S, Reau-Giusti C, Hervé S, Zhu KH, Ouédraogo CM, Verhaeghe C, et al. Effects of clitoral reconstruction for female genital mutilation on perinatal outcomes: A retrospective case-control study. J Gynecol Obstet Hum Reprod. 2021;50(5).

17. Komnas Perempuan. Siaran Pers Komnas Perempuan Hari Internasional Menentang Pelukaan dan Pemotongan Genital Perempuan (P2GP). Jakarta; 2021. p. 1-4.

18. The Community of Practice on Female Genital Mutilation. National laws on FGM - copfgm.org [Internet]. 2021 [cited 2022 Jan 12]. Available from: https://copfgm.org/2021/07/national-laws-on-fgm

19. Sakeah E, Debpuur C, Aborigo RA, Oduro AR, Sakeah JK, Moyer CA. Persistent female genital mutilation despite its illegality: Narratives from women and men in northern Ghana. PLoS One. 2019;14(4):1-14.

20. WHO. Sexual and reproductive health: female genital mutilation and other harmful practices. 2015;1-4. Available from: http://www.who.int/reproductivehealth/topics/fgm/prevalence/en

21. Bappenas. Pilar Pembangunan Sosial. 2020. 133 p.

22. Programme J. Sustaining the Momentum Performance Performance Report. 2020; 